\title{
CAPES/FIPSE \\ Relatório da Experiência na Faculdade de Direito da Universidade do Texas, Austin
}

\author{
Melissa Guimarães Castello1
}

1. DADOS DO PROJETO

1.1. Título: "Responsabilidade Ambiental: $\odot$ Futuro do Princípio da Precauçăo e da Regulação no Brasil e nos Estados Unidos"

1.2. Coordenador brasileiro: Prof. Cezar Saldanha Souza Junior

1.3. Universidade: UFRGS - Universidade Federal do Rio Grande do Sul

1.4. Coordenadora americana: Patricia Hansen

1.5. Universidade: UT - University of Texas

\section{DISCIPLINASCURSADAS}

Disciplina Professor Carga Horária
International Trade Patrícia Hansen $3 \mathrm{~h} / \mathrm{sem}$
Comparative Environmental Law Antonio Benjamin $3 \mathrm{~h} / \mathrm{sem}$
Protection of Human Rights in International Law Steven Ratner $3 \mathrm{~h} / \mathrm{sem}$
Art of Comparison BasilMarkesinis $1 \mathrm{~h} / \mathrm{sem}$

\subsection{Breve relato do conteúdo das disciplinas:}

International Trade

A disciplina centrava-se na análise da estrutura da Organização Mundial do Comércio - OMC, com ênfase nas normas sobre solução de conflitos no comércio internacional de mercadorias. Foram estudados vários casos, e a análise foi bem aprofundada. Conforme previsto

\footnotetext{
1 Advogada nas areas de direito tributário e internacional, graduada na Universidade Federal do Rio Grande do Sul em 2003, e atualmente cursando a Especialização em Direito Internacional da UFRGS. Tive a oportunidade de ser bolsista da CAPES, no Consórcio em Educaçăo Superior Brasil - Estados Unidos, através do qual cursei um semestre da graduação na Universidade do Texas, no primeiro semestre de 2003, motivo pelo qual agradeço aos professores da Faculdade de Direito da UFRGS, e em especial à Professora Cláudia Lima Marques, pelo empenho na conquista e manutençăo destas bolsas.
} 
no programa da disciplina, a prestação de serviços internacionais e a regulação das marcas e patentes não foram estudadas, para que se pudesse estudar com mais detalhes as regras do comércio de mercadorias.

O livro texto designado é muito bom e atualizado (publicado em 2002), e todas as leituras extras eram relevantes, especialmente as publicaçöes nos jornais de matérias relacionadas às estudadas em aula.

As aulas foram, ministradas para uma turma de aproximadamente sessenta alunos, se deram con o método socrático, ideal para a estrutura das aulas na Faculdade de Direito nos EUA, onde os alunos costumam se dedicar exclusivamente aos estudos, tendo tempo, portanto, para realizar as leituras prévias.

Enfim, com a disciplina obtive uma idéia geral das regulações do comércio intemacional, que era o meu objetivo.

\section{Comparative Environmental Law}

Esta disciplina tinha apenas quinze alunos em sala de aula, o que foi ótimo, pois estimulou o diálogo e a troca de idéias entre os alunos.

O conteúdo abordado foi bem amplo, a partir de uma análise comparativa do direito dos países mais avançados na proteção ao meio ambiente, e de extensa bibliografia. As leituras designadas, aliás, foram excelentes e as mais recentes que existiam dentro do assunto.

A disciplina foi essencial para aprofundar meus conhecimentos de direito ambiental, tendo contato com o que há de mais moderno no mundo, em relação à matéria. Achei tão interessante que acabei escrevendo un trabalho dentro deste assunto.

\section{Protection of Human Rights in International Law}

Foi, sem dúvidas, a disciplina mais instigante e mais difícil, una vez que o ritmo da aula era intenso, e o professor extremamente exigente.

A disciplina abordou as mais diversas questōes de direitos humanos que podem suscitar debates internacionais, de forma organizada e com a devida profundidade, calcada em bibliografia recente e relevante ao estudo da matéria.

Foi adotado o método socrático, com leituras prévias dos tópicos que seriam discutidos em aula. A aula era ministrada de forma exemplat e com muita didática.

A avaliaçăo desta disciplina foi bem diferente da avaliação usualmente adotada no Brasil: a prova, que consistia na análise de um caso prático, em que o aluno assumia a posição de uma das partes e tinha que discorrer sobre todos os argumentos a favor e contrários ao seu cliente, podia ser levada para casa, e os alunos tinhan um prazo de oito horas para elaborá-la. O caso abordava quase todas as questóes discutidas en aula de forma extremamente inteligente.

Graças à disciplina, entendi os métodos de proteção dos direitos humanos na esfera internacional e conheci alguns casos práticos em que esses métodos foram utilizados. 


\section{Art of Comparison}

O tema da disciplina era direito comparado, com ênfase em ensinar o aluno, na prática, a realizar um estudo comparativo entre diversos sistemas jurídicos. Para tanto, enfatizou-se questões atinentes à responsabilidade civil, demonstrando-se que, muito embora as regras jurídicas fossem distintas entre os países, a aplicação delas a um caso prático geralmente levava a soluçôes semelhantes, pois o conteúdo moral das regras era o mesmo.

Os livros indicados traziam o que há de mais novo na matéria abordada, e a aula foi ministrada de modo bem informal e descontraído, ideal para turmas pequenas como a da disciplina.

\section{COMENTÁRIOS GERAIS SOBREMINHA EXPERIÊNCIA}

O semestre que passei em Austin foi extremamente proveitoso, pois aprendi muito sobre o sistema jurídico americano, aprimorei meu inglês e entendi melhor a cultura dos norteamericanos. Foi útil, em especial, para aprender novas técnicas de estudo e para aprofundar meus conhecimentos em direito internacional. Acho que o aprendizado que tive lá será muito útil para a minha vida profissional, em um mercado em que conhecer o jargão jurídico em inglês é cada vez mais importante.

A Universidade do Texas tem uma infra-estrutura fantástica para receber os alunos, com bibliotecas riquíssimas e um ambiente ideal para a pesquisa e o estudo. Há, ainda, profundo interesse em assuntos relacionados à Améxica Latina, com diversos centros de estudos e projetos de pesquisa nárea, o que propicia oportunidades para expormos um pouco da nossa cultura. 